\title{
May argyrophilic nucleolar organizing region-associated protein synthesis be used for selecting the most reliable dose of drugs such as rhamnetin in cancer treatments?
}

\author{
Ertekin $\mathrm{T}^{1}$, Bozkurt $\mathrm{O}^{2}$, Eroz $\mathrm{R}^{3}$, Nisari $\mathrm{M}^{1}$, Bircan $\mathrm{D}^{4}$, Nisari $\mathrm{M}^{5}$, Unur $\mathrm{E}^{1}$ \\ Erciyes University Medical Faculty, Department of Anatomy, Kayseri, Turkey. tolga.ertekin@yahoo.com.tr
}

\begin{abstract}
BACKGROUND: Rhamnetin is a flavonoid that has antioxidant, anti-inflammatory and anti-cancer effects. Nucleolar-organizing regions are the ribosomal genes region. We aimed to identify whether rhamnetin has an effect on cell proliferation and whether AgNOR proteins may be used for the detection of therapeutic benefits of the drugs and new metabolites, which have the potential of being used for cancer treatments.

METHODS: Twenty-four mice with Ehrlich's ascites carcinoma (EAC) were randomly assigned to three main groups as positive control, and groups 2 and 3 treated intraperitoneally with rhamnetin $(100 \mu \mathrm{g} / \mathrm{kg}$ and $200 \mu \mathrm{g} /$ $\mathrm{kg}$, respectively). All the animals were sacrificed on day16, $24 \mathrm{~h}$ after the last dose; the tumors, which developed at the site of injection were removed. Then, mean AgNOR number and total AgNOR area/nuclear area (TAA/NA) were detected for each mouse.

RESULTS: Significant differences were detected among all groups for mean AgNOR number $(p=0.000)$ and TAA/NA ratio $(p=0.000)$. While the difference between positive control and Rhamnetin $(100 \mu \mathrm{g} / \mathrm{kg}) \mathrm{group}$ was not significant $(p=0.387)$, there are significant differences between positive control and Rhamnetin $(200 \mu \mathrm{g} /$ $\mathrm{kg})$ group $(p=0.000)$ and between Rhamnetin $(100 \mu \mathrm{g} / \mathrm{kg})$ and Rhamnetin $(200 \mu \mathrm{g} / \mathrm{kg})$ groups $(p=0.000)$ for TAA/NA ratio.

CONCLUSION: Rhamnetin has an important role in preventing cancer formation. Our study showed that mean AgNOR numbers and TAA/NA values may be used also as biomarkers for evaluating the success rate of the performed therapeutic strategy and accurate dose selection for the management of the disease (Tab. 3, Fig. 3, Ref. 45). Text in PDF www.elis.sk.

KEY WORDS: NOR, AgNORs, rhamnetin, cancer treatments, rDNA.
\end{abstract}

\section{Introduction}

Cancer is a major health problem throughout the world and the leading major cause of human mortality exceeded only by cardiovascular disease $(1,2)$. It is known that cancer treatment is usually based on surgical removal, radiotherapy, immunotherapy, hormonal therapy and chemotherapy, with the purpose of increasing the patients' survival (3). Most of the currently available anticancer drugs fail to differentiate between normal and neoplastic cells or to overcome primary or secondary resistance mechanisms involved in cancer cells $(4,5)$. In this regard, there is an urgent need for novel pharmaceutical agents with tumor selectivity and

${ }^{1}$ Erciyes University Medical Faculty, Department of Anatomy, Kayseri, Turkey, ${ }^{2}$ Nevsehir Hacibektas Veli University, Semra and Vefa Kucuk Health High School, ${ }^{3}$ Duzce University Medical Faculty, Department of Medical Genetics, ${ }^{4}$ Duzce University Medical Faculty, Department of Medical Biology, and ${ }^{5}$ Nuh Naci Yazgan University, Faculty of Healt Science

Address for correspondence: T. Ertekin, Erciyes University, Medical Faculty, Department of Anatomy, 38039 Talas, Kayseri, Turkey. Phone: +90.352.2076666, Fax: +90.352.4374931

Acknowledgement: This work was supported by Erciyes University (EUBAP- THD-2016-6499). specificity, but with limited side effects. The prevention of cancer through the ingestion of vegetables and fruits has been suggested in human epidemiologic studies, and the focus of drug development has been shifted to natural chemotherapeutic agents found in plants (6-8). Plants have been used as medicine for a long time and about $70 \%$ of anticancer drugs are produced from natural products or their derivatives $(9,10)$. Rhamnetin, a flavonoid, is a bioactive polyphenolic compound, which is generally found in vegetables and fruits (11), and has a flavan nucleus consisting of two benzene rings combined by an oxygen-containing pyran ring. Rhamnetin is known to function as an antioxidant $(12,13)$ and alkylperoxyl radical-scavenging, (14) anti-inflammatory (15) xanthine oxidase inhibitory (16) and antiviral agent (17).

As a spontaneous murine mammary adenocarcinoma, the Ehrlich ascites tumor cells (18) have the potential to grow in almost all strains of mice as a rapidly growing carcinoma with very aggressive behavior (19). It has similarities with human tumors and is sensitive to chemotherapy (20). Various studies showed the beneficial use of Ehrlich's ascitic carcinoma (EAC) and solid tumor (EST) models as a valuable tool in exploring biological activities in cancer and evaluating the effect of several chemical compounds $(19,21,22)$. 

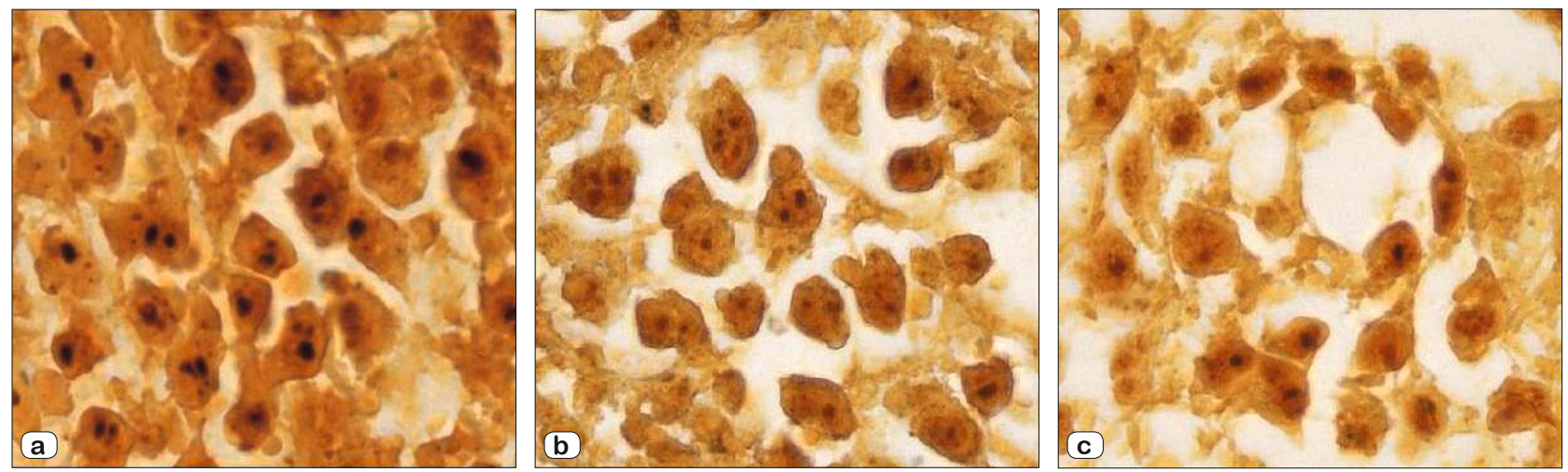

Fig. 1. Demonstrative examples of stained AgNOR cells (a - positive control; b - rhamnetin (100 $\mu \mathrm{g} / \mathrm{kg})$ group and c - rhamnetin $(200 \mu \mathrm{g} / \mathrm{kg})$ group.

The nucleolus is an important structure within the cell nucleus. Nucleolus is the site where ribosomal RNA and ribosomal subunits are made from proteins. The size of nucleolus and its organization are directly associated with ribosome production and exhibit the functional compartmentation of the nucleolar machinery.

Nucleolar-organizing regions (NORs) are the ribosomal genes region on chromosomes and is composed of ribosomal DNA (rDNA) and proteins, while some of them are argyrophilic. These regions are transcribed into ribosomal RNA, which processes the preribosomes in the nucleolus to become part of mature ribosomes in the cytoplasm (23). The NORs can be stained with silver when they are active. Thus, those proteins are referred to as argyrophilic NOR-associated proteins (AgNORs), while the silver-staining method is the most reliable to show nucleoli during the interphase (24). Numerous studies have been carried out on the importance of the interphase quantity of AgNOR proteins in hair root cells of humans $(25,26)$, buccal epithelial and blood cells of Down syndrome infants and healthy persons (27-29), possible effects of carbonmonoxide ( $\mathrm{CO}$ ) exposure on the AgNOR protein synthesis of the cells of the heart, lung and femoral muscle (30-33) and ischemia/reperfusion injury (34). However, to our knowledge, there is no study about the relation between AgNOR proteins and the effects of rhamnetin exposure on EST in literature. Thus, we carried out the current study to show this association.

\section{Methods}

\section{Experimental animals}

All animal procedures and experimental protocols were approved by the Experimental Animals Ethics Committee, Erciyes University, Turkey (13/146 - 11/12/2013). Balb/c mice, about 6-8 weeks old with an average body weight of 25-30 g were procured from Laboratory Animal Unit of Experimental and Clinical Research Center, Erciyes University-and housed under controlled conditioning $\left(25 \pm 1{ }^{\circ} \mathrm{C}\right.$ constant temperature, $55 \%$ relative humidity, $12 \mathrm{~h}$ dark/light cycles). Food and water were allowed ad libitum during the study period. The mice were acclimatized to laboratory conditions during 7 days before the commencement of experiment.

\section{Tumor cells preparation and transplantation}

EAC cells were obtained from Anatomy Department of Medical Faculty, Erciyes University. The tumor cells were maintained in our laboratory by serial intraperitoneal (ip.) passage in male Balb/c mice for 7-10 days. EAC cells were tested for viability and contamination using trypan blue dye exclusion technique. Cell viability was usually found to be $95 \%$ or more. Tumor cell suspensions were prepared in Phosphate Buffered Saline (PBS).

Mice were inoculated subcutaneously at their back with $0.1 \mathrm{ml}$ of EAC working suspension containing $1 \times 10^{6}$ of EAC cells. The day of tumor implantation was designed as day 1 . Two hours after inoculation, 24 mice were randomly assigned to 3 main groups by 8 mice each, and treated as follows. The first group received a vehicle injection (PBS) and served as EST-positive control group. The mice from groups II and III were treated intraperitoneally with Rhamnetin (100 $\mu \mathrm{g} / \mathrm{kg}$ and $200 \mu \mathrm{g} / \mathrm{kg}$, respectively) every day. All the animals were sacrificed on day 16, $24 \mathrm{~h}$ after the last dose. The tumors, which developed at the site of injection were removed and fixed in $10 \%$ formaldehyde and embedded in paraffin blocks for AgNOR staining.

\section{AgNOR detection}

The animals' tissues were dissected (approximately 1 x 1 x 1 $\mathrm{cm}^{3}$ in size). After routine histological follow up, the slides including $5-\mu \mathrm{m}$ thick sections were prepared and deparaffinized in xylene and then rehydrated in graded alcohol solutions before AgNOR staining. The slides were air-dried for $15 \mathrm{~min}$ at room temperature and fixed using fixative solution $(3: 1$ ratio of methanol and acetic acid) for $5 \mathrm{~min}$. AgNOR staining method was carried out according to the Benn and Perle protocol, while the Lindner protocol was used with a slight modification for all slides obtained from three groups $(35,36)$. The cells staining with AgNOR were viewed via a light microscope (Eclipse 80i, Nikon) and photographed using a digital camera (Digital Sight DS-fil, Nikon). The captured images of the cells were transferred to image processing software (ImageJ version 1.47t, National Institutes of Health, Bethesda, Maryland, USA). Fifty nuclei were evaluated for each slide. The mean AgNOR number was counted and total AgNOR area per nuclear area (TAA/NA) was calculated via "freehand selection" 
Tab. 1. TAA/NA and mean AgNOR number values of positive controls $(\mathrm{n}=8)$, rhamnetin $(100 \mu \mathrm{g} / \mathrm{kg})(\mathrm{n}=8)$ and rhamnetin $(200 \mu \mathrm{g} / \mathrm{kg})$ $(\mathrm{n}=8)$ groups.

\begin{tabular}{lcc}
\hline Groups & TAA/NA & $\begin{array}{c}\text { Mean AgNOR } \\
\text { number }\end{array}$ \\
\hline Positive Control-1 & $0.1529 \pm 0.0869$ & $1.700 \pm 0.9313$ \\
Positive Control-2 & $0.1504 \pm 0.0656$ & $2.300 \pm 1.1824$ \\
Positive Control-3 & $0.1524 \pm 0.0767$ & $2.8800 \pm 1.5733$ \\
Positive Control-4 & $0.1517 \pm 0.0903$ & $2.700 \pm 1.6568$ \\
Positive Control-5 & $0.1526 \pm 0.0925$ & $2.3800 \pm 1.2103$ \\
Positive Control-6 & $0.1512 \pm 0.0548$ & $2.0400 \pm 1.1058$ \\
Positive Control-7 & $0.1502 \pm 0.0471$ & $1.7200 \pm 0.0858$ \\
Positive Control-8 & $0.1518 \pm 0.0764$ & $1.8800 \pm 1.0427$ \\
Rhamnetin $(100 \mu \mathrm{g} / \mathrm{kg})-1$ & $0.1470 \pm 0.1774$ & $1.9400 \pm 1.0383$ \\
Rhamnetin $(100 \mu \mathrm{g} / \mathrm{kg})-2$ & $0.1466 \pm 0.0517$ & $2.0200 \pm 1.1516$ \\
Rhamnetin $(100 \mu \mathrm{g} / \mathrm{kg})-3$ & $0.1442 \pm 0.0543$ & $1.5010 \pm 0.7626$ \\
Rhamnetin $(100 \mu \mathrm{g} / \mathrm{kg})-4$ & $0.1489 \pm 0.0659$ & $1.6400 \pm 0.8514$ \\
Rhamnetin $(100 \mu \mathrm{g} / \mathrm{kg})-5$ & $0.1473 \pm 0.0514$ & $1.1800 \pm 0.3881$ \\
Rhamnetin $(100 \mu \mathrm{g} / \mathrm{kg})-6$ & $0.1483 \pm 0.0535$ & $1.5000 \pm 0.7627$ \\
Rhamnetin $(100 \mu \mathrm{g} / \mathrm{kg})-7$ & $0.1489 \pm 0.0896$ & $1.4600 \pm 0.7879$ \\
Rhamnetin $(100 \mu \mathrm{g} / \mathrm{kg})-8$ & $0.1466 \pm 0.0473$ & $1.8000 \pm 0.9035$ \\
Rhamnetin $(200 \mu \mathrm{g} / \mathrm{kg})-1$ & $0.1241 \pm 0.0749$ & $1.3600 \pm 0.6627$ \\
Rhamnetin $(200 \mu \mathrm{g} / \mathrm{kg})-2$ & $0.1268 \pm 0.0519$ & $1.8400 \pm 0.7384$ \\
Rhamnetin $(200 \mu \mathrm{g} / \mathrm{kg})-3$ & $0.1282 \pm 0.0940$ & $2.1201 \pm 0.9612$ \\
Rhamnetin $(200 \mu \mathrm{g} / \mathrm{kg})-4$ & $0.1264 \pm 0.0865$ & $2.1200 \pm 1.0428$ \\
Rhamnetin $(200 \mu \mathrm{g} / \mathrm{kg})-5$ & $0.1248 \pm 0.0480$ & $1.6600 \pm 0.8478$ \\
Rhamnetin $(200 \mu \mathrm{g} / \mathrm{kg})-6$ & $0.1251 \pm 0.0492$ & $1.9010 \pm 0.9091$ \\
Rhamnetin $(200 \mu \mathrm{g} / \mathrm{kg})-7$ & $0.1263 \pm 0.0549$ & $1.6000 \pm 0.6388$ \\
Rhamnetin $(200 \mu \mathrm{g} / \mathrm{kg})-8$ & $0.1255 \pm 0.0594$ & $1.9000 \pm 0.7889$ \\
\hline
\end{tabular}

TAA/NA - Total AgNOR area/Nuclear area

tool for each nucleus. A demonstrative example of AgNOR staining of cells were given in Figure 1 (a: positive control; b: $100 \mu \mathrm{g} /$ $\mathrm{kg}$ rhamnetin group and c: $200 \mu \mathrm{g} / \mathrm{kg}$ rhamnetin group.

\section{Statistical analysis}

Statistical analysis was done by using Statistical Package for Social Sciences (SPSS, Inc., Chicago, Illinois, USA) for Windows 22.0. The descriptive statistical methods (mean and standard deviation (SD)) and Mann-Whitney U and Kruskall-Wallis tests were used to compare all three groups (positive control, and Rhamnetin $(100 \mu \mathrm{g} / \mathrm{kg})$ and Rhamnetin $(200 \mu \mathrm{g} / \mathrm{kg})$ groups $)$. Results were given as mean $\pm \mathrm{SD}$, and $\mathrm{p}<0.05$ was accepted as statistically significant.

\section{Results}

Mean AgNOR number and TAA/NA ratio were detected in positive control, and rhamnetin $(100 \mu \mathrm{g} / \mathrm{kg}$ and $200 \mu \mathrm{g} / \mathrm{kg})$ groups (Tab. 1). When we compared the three groups, significant differences were detected among groups for mean AgNOR number $\left(x^{2}\right.$ $=50.774, \mathrm{p}=0.000)$ and TAA/NA ratio $\left(x^{2}=47.082, \mathrm{p}=0.000\right)$ (Tab. 2, Figs 2 and 3). While the difference was not significant between positive control and rhamnetin $(100 \mu \mathrm{g} / \mathrm{kg})$ group $(\mathrm{Z}=$ $-0.387, p=0.387)$, the differences between positive control and rhamnetin $(200 \mu \mathrm{g} / \mathrm{kg})$ group $(Z=-6.274, \mathrm{p}=0.000)$ and between Rhamnetin $(100 \mu \mathrm{g} / \mathrm{kg})$ and Rhamnetin $(200 \mu \mathrm{g} / \mathrm{kg})$ groups $(\mathrm{Z}=$ $-5.521, \mathrm{p}=0.000)$ were significant for TAA/NA ratio. When we considered the mean AgNOR number, the differences between positive control and rhamnetin $(100 \mu \mathrm{g} / \mathrm{kg})$ group $(Z=-7.011, \mathrm{p}$ $=0.000)$, positive control and Rhamnetin $(200 \mu \mathrm{g} / \mathrm{kg})$ group $(\mathrm{Z}$ $=-3.681, \mathrm{p}=0.000)$ and rhamnetin $(100 \mu \mathrm{g} / \mathrm{kg})$ and rhamnetin $(200 \mu \mathrm{g} / \mathrm{kg})$ groups $(\mathrm{Z}=-3.698, \mathrm{p}=0.000)$ were significant for mean AgNOR number (Tab. 3, Figs 2 and 3).

\section{Discussion}

Cancer is an important health problem all over the world. Therefore, different treatment strategies have been used for its management. One of them is based on phytothrerapy, in which natural chemotherapeutic agents from plants such as rhamnetin are used. Rhamnetin is extracted from Hippophae rhamnoides Linn. It is a flavonoid compound also containing a polyphenol structure. It functions as a specific inhibitor of Notch-1 pathway via enhancing miR-34a level. The inhibition of Notch-1 activation may lead to anticancer effects. Therefore, rhamnetin has a role in the modulation of cancer cell survival (37). Hui Jia et al., reported that rhamnetin (at non-cytotoxic concentration) has an effect on enhancing the efficacy of anti-tumor agents via miR-34amediated Notch-1 suppression in hepatocellular carcinoma cells (HCC). Due to therapeutic effects of rhamnetin in the treatment of HCC, this molecule could provide the basis for developing a specific sensitizer of anti-tumor drugs (38).

Notch-1 also mediates the EMT (epithelial-mesenchymal transition) process that is associated with multi-drug resistance

Tab. 2. Comparison of three groups for mean AgNOR number and TAA/NA ratio.

\begin{tabular}{lcccc}
\hline & TAA/NA & AgNOR Number & $\mathrm{p}$ & $x^{2}$ \\
\hline Positive Control & $0.1516 \pm 0.07463$ & $2.200 \pm 1.2820$ & $0.000^{*}$ & $47.082^{*}$ \\
Rhamnetin $(100 \mu \mathrm{g} / \mathrm{kg})$ & $0.1473 \pm 0.0838$ & $1.630 \pm 0.0444$ & & \\
Rhamnetin $(200 \mu \mathrm{g} / \mathrm{kg})$ & $0.1259 \pm 0.0664$ & $1.813 \pm 0.0431$ & $0.000^{\&}$ & $50.774^{\&}$ \\
\hline
\end{tabular}

*: For TAA/NA, \&: For Mean AgNOR number, TAA/NA: Total AgNOR area/Nuclear area

Tab. 3. Double comparison of all groups for mean AgNOR number and TAA/NA ratio.

\begin{tabular}{|c|c|c|c|c|}
\hline \multirow[b]{2}{*}{ Groups } & \multicolumn{2}{|c|}{ For TAA/NA } & \multicolumn{2}{|c|}{ For mean AgNOR number } \\
\hline & $\mathrm{p}$ & $\mathrm{Z}$ & $\mathrm{p}$ & Z \\
\hline Positive control - Rhamnetin $(100 \mu \mathrm{g} / \mathrm{kg})$ & 0.387 & -0.866 & 0.000 & -7.011 \\
\hline Positive control - Rhamnetin $(200 \mu \mathrm{g} / \mathrm{kg})$ & 0.000 & -6.274 & 0.000 & -3.681 \\
\hline Rhamnetin $(100 \mu \mathrm{g} / \mathrm{kg})$-Rhamnetin $(200 \mu \mathrm{g} / \mathrm{kg})$ & 0.000 & -5.521 & 0.000 & -3.698 \\
\hline
\end{tabular}

TAA/NA: Total AgNOR area/Nuclear area 


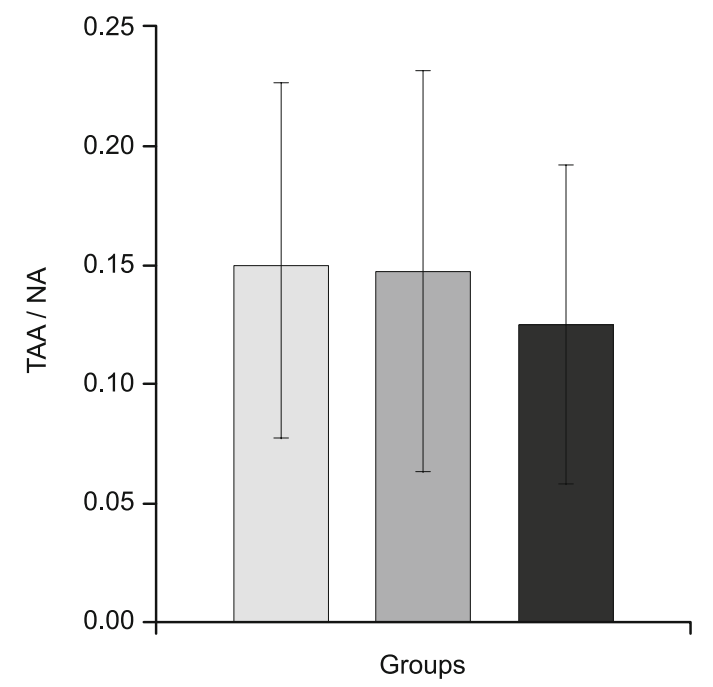

Positive control

$\square$ Rhamnetin $(100 \mu \mathrm{g} / \mathrm{kg})$

Rhamnetin $(200 \mu \mathrm{g} / \mathrm{kg})$

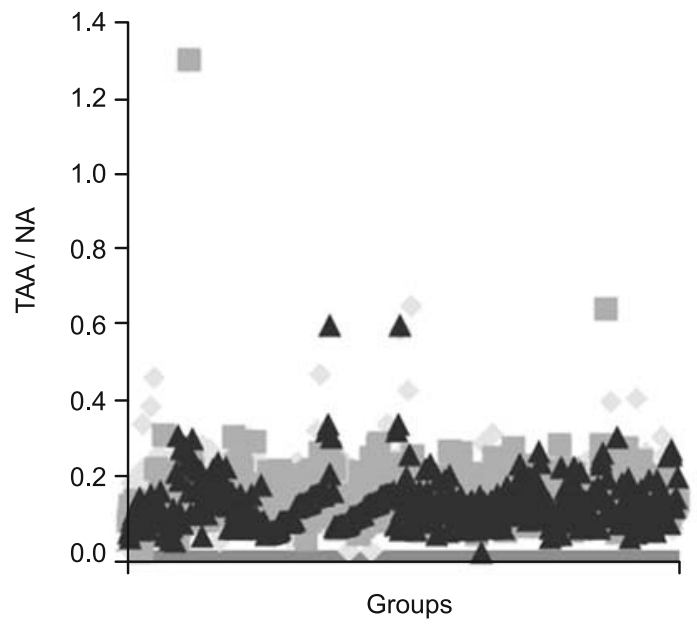

Positive control

Rhamnetin $(100 \mu \mathrm{g} / \mathrm{kg})$

Rhamnetin $(200 \mu \mathrm{g} / \mathrm{kg})$

Fig. 2. Comparison of three groups for TAA/NA values (a - mean values for each groups, $b$ - each value for all groups)

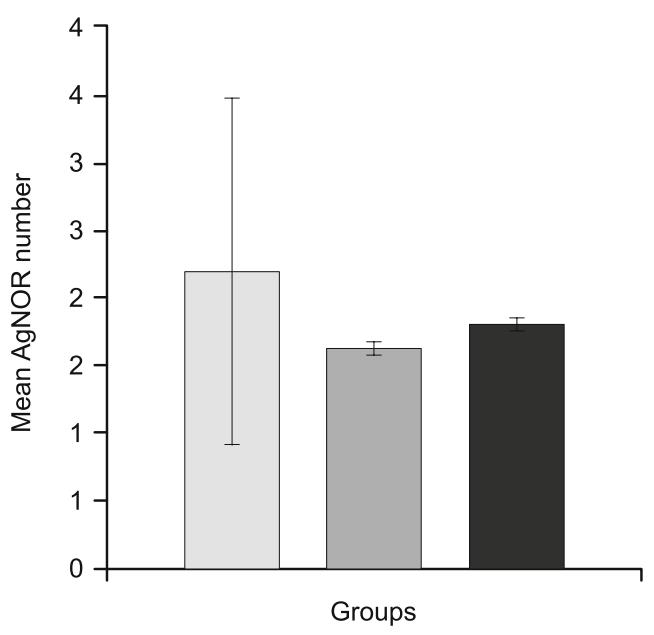

Positive control

$\square$ Rhamnetin $(100 \mu \mathrm{g} / \mathrm{kg})$

Rhamnetin $(200 \mu \mathrm{g} / \mathrm{kg})$

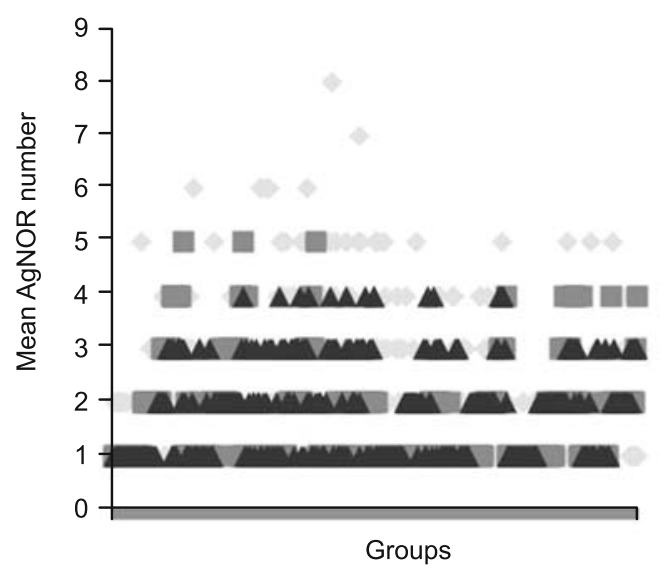

Positive control

$\square$ Rhamnetin $(100 \mu \mathrm{g} / \mathrm{kg})$

Rhamnetin $(200 \mu \mathrm{g} / \mathrm{kg})$

Fig. 3. Comparison of three groups for mean AgNOR numbers (a - mean values for each groups, $b$ - each value for all groups)

(MDR) or metastasis of human cancers (37). Thus, the inhibition of Notch-1 activation is an important strategy in the treatment of human cancer. Rhamnetin treatment increased the activity of sorafenib and traditional chemotherapeutic agents and also inhibited the EMT process of HepG2 cells (39). Rhamnetin is thus an important natural product for developing a novel therapeutic strategy in human cancers. Therefore, metabolites such as rhamnetin obtained from natural plants are important sources for chemical synthesis and structural modification of new drugs and development of new strategy for cancer treatments.

During the interphase, NORs are associated with a great number of regulatory proteins and they have roles as functional subunits of the nucleolus (40). Alterations in AgNOR protein amounts also reflect the metabolic activities of the cells. We performed various numbers of studies on malign and benign lesions (41-45). In these studies, we evaluated mean AgNOR number and TAA/NA ratio 
as a new approach that may contribute to routine cytopathology for determining the proliferation activity of cells in malignant and benign lesions. In the current study, we aimed to identify whether rhamnetin has an effect on cell proliferation and whether the detection of AgNOR protein amounts may be used to detect the therapeutic benefits of the drugs and new metabolites that have a potential to be used in cancer treatments. To our knowledge, this is the first study on the evaluation of AgNOR amounts in EST that are exposed to different concentrations of rhamnetin. In our current study, when we compared the three (positive control, rhamnetin $(100 \mu \mathrm{g} / \mathrm{kg})$ and rhamnetin $(200 \mu \mathrm{g} / \mathrm{kg}))$ groups, significant differences were detected between them for mean AgNOR number and TAA/NA ratio. While the difference between Rhamnetin (100 $\mu \mathrm{g} / \mathrm{kg}$ ) and positive control group was not significant, statistically significant differences were found between rhamnetin $(200 \mu \mathrm{g} / \mathrm{kg})$ and both positive control and rhamnetin $(100 \mu \mathrm{g} / \mathrm{kg})$ groups for TAA/NA ratio. Therefore, it may be said that in cancer treatment, rhamnetin at a dose increased up to $200 \mu \mathrm{g} / \mathrm{kg}$ is more effective than when administered at a dose of $100 \mu \mathrm{g} / \mathrm{kg}$.

When we consider mean AgNOR number, statistically significant differences were detected between positive control and rhamnetin $(100 \mu \mathrm{g} / \mathrm{kg})$, positive control and rhamnetin $(200 \mu \mathrm{g} /$ $\mathrm{kg})$, and rhamnetin $(100 \mu \mathrm{g} / \mathrm{kg})$ and rhamnetin $(200 \mu \mathrm{g} / \mathrm{kg})$ groups for mean AgNOR number. Counting AgNOR dots under the light microscope is subjective and poorly reproducible. Additionally, single AgNOR dots can be clustered together or overlapped and counting alone does not take into consideration the size of each silver-stained dot that varies in amount. In metabolically active and cancer cells, not only gene expression and its products but also cell morphology, and synthesis capacity, as well as both number of biomolecules and size of cells and their nuclei were altered. Thus, more accurate knowledge about the metabolic and proliferative activity of the cells could be obtained by using new approaches based on the calculation of NOR area and nucleus area values. Identification of new biomarkers for discriminating benign and malignant lesions and the detection of the success rate of the performed therapeutic strategy is important for enhancing the diagnostic accuracy and management of treatment strategy for increasing the success rate of therapy.

The current study showed that the expression capacity of rRNA gene, as detected via total TAA/NA and/or AgNOR number per total nuclear number, decreased depending on the exposed rhamnetin concentration. It may be said that rhamnetin has an important role in prevention of tumor formation and triggers or supresses the synthesis of some other proteins that have important features and functions in signaling the transduction pathways and gene expression regulation in tumor cells.

\section{Conclusion}

To obtain more accurate knowledge about the current topic, additional studies including those on different metabolic pathways that have therapeutic features should be performed in various types of cancer. In this manner, good therapeutic approaches may be developed for making the management of diseases more accurate. Additionally, because this technique is simple, cheap, and serves as a valuable marker to evaluate the ribosomal gene activity in different metabolic durations of various cells, it has important advantages.

It was detected that rhamnetin has an important role against cancer formation. The current study indicated that the detection of both the AgNOR values may be used also as a biomarker for detecting the success rate of the performed therapeutic strategy and selection of a reliable dose for accurate management of the disease.

\section{References}

1. Babasaheb PB, Shrikant SG, Ragini GB, Jalinder VT, Chandrahas NK. Synthesis and biological evaluation of simple methoxylated chalcones as anticancer, anti-inflammatory and antioxidant agents. Bioorg Med Chem 2010; 18: 1364-1370.

2. Varmus H. The New Era in Cancer Research, Science 2006; 26: 11621165 .

3. Videira M, Reis RL, Brito MA. Deconstructing breast cancer cell biology and the mechanisms of multidrug resistance. Biochim Biophys Acta 2014; 1846: 312-325.

4. Chari RV. Targeted delivery of chemotherapeutics: tumor-activated prodrug therapy. Adv Drug Deliv Rev 1998; 6: 89-104.

5. Devasagayam TPA, Sainis KB. Immune system and antioxidants: especially those involved with Indian medicinal plants. Indian J Exp Biol 2002; 40: 639-655.

6. Ziegler RG. A review of epidemiologic evidence that carotenoids reduce the risk of cancer. J Nutr 1989; 119: 116-122.

7. Block G, Patterson B, Subar A. Fruit, vegetables, and cancer prevention: a review of the epidemiological evidence. Nutr Cancer 1992; 18: 1-29.

8. Mayne ST. Beta-carotene, carotenoids, and disease prevention in humans. Faseb J 1996; 10: 690-701.

9. Rocha AB, Lopes RM, Schwartsmann G. Natural products in anticancertherapy. Curr Opin Pharmacol 2001; 1: 364e-369.

10. Houghton JA. Apoptosis and drug response. Curr Opin Oncol 1999; 11: $475 \mathrm{e}-481$

11. Ozipek M, Calis I, Ertan M, Rüedi P. Rhamnetin 3-p-coumaroylrhamninoside from Rhamnus petiolaris. Phytochemistry 1994; 37: 249-253.

12. Tung YT, Chang WC, Chen PS, Chang TC, Chang ST. Ultrasoundassisted extraction of phenolic antioxidants from Acacia confusa flowers and buds. J Sep Sci 2011; 34: 844-851.

13. Igarashi K, Ohmuma M. Effects of isorhamnetin, rhamnetin, and quercetin on the concentrations of cholesterol and lipoperoxide in the serum and liver and on the blood and liver antioxidative enzyme activities of rats. Biosci Biotechnol Biochem 1995; 59: 595-601.

14. Sawa T, Nakao M, Akaike T, Ono K, Maeda H. Alkylperoxyl radicalscavenging activity of various flavonoids and other phenolic compounds: implications for the anti-tumor-promoter effect of vegetables. J Agric Food Chem 1999; 47: 397-402.

15. Mondal A, Rajalingam D, Kumar Maity T. Anti-inflammatory effect of O-methylated flavonol 2-(3,4-dihydroxy-phenyl)-3,5- dihydroxy7-methoxy-chromen-4-one obtained from Cassia sophera Linn in rats. J Ethnopharmacol 2013; 147: 525-529. 
16. Nessa F, Ismail Z, Mohamed N. Xanthine oxidase inhibitory activities of extracts and flavonoids of the leaves of Blumea balsamifera. Pharm Biol 2010; 48: 1405-1412.

17. Liu AL, Shu SH, Qin HL, Lee SM, Wang YT, Du GH. In vitro antiinfluenza viral activities of constituents from Caesalpinia sappan. Planta Med 2009; 75: 337-339.

18. Ehrlich P, Apolant H. Beobachtungen über maligne Mäusetumoren. Berliner klinische Wochenschrift 1905; 42: 871-874.

19. Calixto-Campos C, Zarpelon AC, Corrêa M, Cardoso RD, PinhoRibeiro FA, Cecchini R et al. The Ehrlich tumor induces pain-like behavior in mice: a novel model of cancer pain for pathophysiological studies and pharmacological screening. Bio Med Res Int 2013; 2013: 624815.

20. Gherman C, Pileczki V, Cojocneanu Petric R, Braicu C, Răpuntean $\mathrm{S}$ et al. In vitro studies for evaluation the antitumoral and immunomodulator effect of EGCG on Ehrlich ascites. Arch Zootech 2012; 5: 79-87.

21. Attia WY, Gabry MS, El-Shaikh KA, Othman GA. The anti-tumor effect of bee honey in Ehrlich ascite. Tumor model of mice is coincided with stimulation of the immune cells. Egypt J Immunol. 2008; 15: 169-183.

22. Queiroz LS, Valadares MC, Bincoletto C. Dieamant GC. Ehrlich ascites tumor as a tool in the development of compounds with immunomodulatory properties. Immunopharmacol Immunotoxicol 2004; 26: 511-525.

23. Hernandez-Verdun D. The nucleolus: a model for the organization of nuclear functions. Histochem Cell Biol. 2006; 126: 135-148.

24. Trere D. AgNOR staining and quantifi cation. Micron 2000; 31: 127131.

25. Eroz R, Tasdemir S, Dogan H. Is there any relationship between decreased AgNOR protein synthesis and human hair loosing. Biotech Histochem 2012a; 87: 494-498.

26. Eroz R, Yilmaz S, Cucer N. Argyrophilic nucleolar organizing region associated protein synthesis in hair root cells of humans at different developmental stages and sex. Biotech Histochem 2013a; 88: 267-271.

27. Eroz R, Okur M, Ozkan A, Berik O, Gunes C. Does higher NORs expression affect the developmental stages of down syndrome infants? Genetic Counseling 2012b; 23: 249-253.

28. Selvi B, Demirtas H, Eroz R, Imamoglu N. Investigation of the agedependent AgNOR protein level in buccal epithelial cells of healty individuals. Aging Clinical and Experimental Research 2015; 27: 201-208.

29. Imamoglu N, Eroz R, Canatan H, Demirtas H, Saatci Ç. Nuclear AgNOR protein enhancement in nucleoplasms of peripheral blood lymphocytes of babies/children with Down syndrome. Microsc Res Tech 2016, 79: 133-9.

30. Colakoglu S, Saritas A, Eroz R, Oktay M, Yaykasli KO, Akoz A et al. Is one-time carbon monoxide intoxication harmless? Evaluation by argyrophilic nucleolar-organizing regions staining method. Human and Experimental Toxicology 2015; 34:24-31.

31. Kandis H, Afacan MA, Eroz R, Colakoglu S, Bayramoglu A, Oktay $\mathbf{M}$ et al. Can argyrophilic nucleolar organizing region-associated protein amount be used for the detection of cardiac damage? Human and Experimental Toxicology 2015; 35: 323-31.

32. Saritas A, Gunes H, Colakoglu S, Eroz R, Akoz A, Oktay M et al. Are There Any Effects of Chronic Carbon Monoxide Exposure on Ar- gyrophilic Nucleolar Organizing Region-Associated Protein Synthesis in Rat Myocardium? Human and Experimental Toxicology Early Online: $2015 ; 1-8$.

33. Eroz R, Saritas A, Colakoglu S, Oktay M, Kandis H. Evaluation Of Argyrophilic Nucleolar Organizing Region-Associated Protein Synthesis In Femoral Muscle Cells Of Rats Exposed 3000 Ppm Carbon Monoxide Gas. Konuralp Medical Journal 2016; 8: 9-13.

34. Nisari M, Eroz R, Nisari M, Ertekin T, Oktay M, Kavutcu M. Investigation of argyrophilic nucleolar organizing region. Bratisl Med J 2016; 117 (6): $345-350$

35. Benn PA, Perle M. Chromosome staining and banding techniques. In: Rooney DE, Czepulskowski BH (Eds). Human cytogenetics: Constitutional analysis: A practical approach. London: Oxford University Press, 1986; 91-118.

36. Lindner LE. Improvements in the silver-staining technique for nucleolar organizer regions (AgNOR). J Histochem Cytochem 1993; 41 (3): 439-445.

37. Kang J, Kim E, Kim W, Seong KM, Youn V, Kim JW et al. Rhamnetin and cirsiliol induce radiosensitization and inhibition of epithelial-mesenchymal transition (EMT) by miR-34a-mediated suppression of Notch-1 expression in nonsmall cell lung cancer cell lines. J Biol Chem 2013; 288: 27343-27357.

38. Jia H, Yang Q, Wang T, Caod Y, Jiange Q, Dama $H$ et al. Rhamnetin induces sensitization of hepatocellular carcinoma cells to a small molecular kinase inhibitor or chemotherapeutic agents. Biochimica et Biophysica Acta 2016; 1860: 1417-1430.

39. Bader AG. miR-34 - a microRNA replacement therapy is headed to the clinic. Front Genet 2012; 3: 120.

40. Ploton D, Menager M, Lechki C, Jeannesson P, Visseaux B, Adnet JJ. Silver staining of nucleolus organizer regions (NORs). Application to the study of nucleolar structure and value in pathology. Ann Pathol 1988; 8: $248-252$.

41. Eroz R, Cucer N, Karaca Z, Unluhizarci K, Ozturk F. The evaluation of argyrophilic nucleolar organizing region proteins in fineneedle aspiration samples of thyroid. Endocr Pathol 2011; 22: 74-78.

42. Eroz R, Unluhizarci K, Cucer N, Baltaci D, Oktay M. Kistik Nodüler Guatirli Olgularin Tiroid Hücrelerindeki AgNOR Sayisi ve AgNOR Yüzey Alani/Çekirdek Alani Oraninin Yaş ve Cinsiyete göre Karşilaştirilmasi. Konuralp Tip Dergisi 2012c; 4: 31-35.

43. Eroz R, Unluhizarci K, Cucer N, Ozturk F. The Value Of Argyrophilic Nucleolar Organising Region Protein Determinations in Non-Diagnostic Fine Needle Aspiration Samples (Due To Insufficient Cell Groups) Of Thyroid Nodules. Analytical And Quantitative Cytology And Histology 2013b; 35: 226-232.

44. Eroz R, Cucer N, Unluhizarci K, Ozturk F. Detection and comparison of cutoff values for total AgNOR area/nuclear area and AgNOR number/nucleus in benign thyroid nodules and normal thyroid tissue. Cell Biol Int 2013c; 37: 257-261.

45. Oktay M, Eroz R, Oktay NA, Erdem H, Başar F et al. Argyrophilic nucleolar organizing region associated protein synthesis for cytologic discrimination of follicular thyroid lesions. Biotech Histochem 2015; 90: 179-183. 